\title{
Meteorology on the Southern Frontier of Japan's Empire: Ogasawara Kazuo at Taihoku Imperial University
}

\author{
Masumi Zaiki • Togo Tsukahara
}

Received: 7 April 2007 / Accepted: 9 December 2007 /

Published online: 12 March 2008

(C) National Science Council, Taiwan 2008

\begin{abstract}
This paper outlines some characteristics of the academic activity in the Japanese colonial setting, with special reference to meteorology on the southern colonial frontier of Japan's Empire, through the works of Ogasawara Kazuo at Taihoku Imperial University. We first review the establishment of Japan's overseas meteorological network and the corresponding institutionalization of meteorology in that period. We will then consider Ogasawara's academic works at Taihoku Imperial University, and analyse how a pure scientist shifted to colonial management and justified Japan's expansion as far as Australia and New Zealand. We will examine his moral dilemma, how he wrote his work on tropical climate, and his interpretation of Huntingtonian environmental determinism. Through the analysis of Ogasawara's works, we are able to see at least one aspect of Japan's colonial science, its syncretic nature and pragmatism.
\end{abstract}

Japanese Abstract (タイトル) 『大日本帝国の南方前線の気象学：台北帝国 大学の小笠原和夫』 (著者) 神戸大学 - 学振特研 (SPD) - 財城真寿美; 国際 文化学研究科・教授・塚原東吾 (要旨) 本論文は日本の植民地での科学研 究の歴史的特徵を検討するものである。そのために南方進出への拠点とさ れた台北帝国大学 ・気象学 ・助教授 ・ 小笠原和夫の業績を見てゆく。ま ず当時の日本の気象観測事業の東アジアでの展開と、それに呼応する気象 学の制度化を概観する。さらに台北帝国大学で行われた小笠原の研究業績 を分析する。そもそも純粋科学が、いかにして植民地経営に資する形の知 識生産に至り、最終的にはオーストラリア、ニュージーランドを植民地に すべきであるという膨張主義の正当化に至ったか、そして小笠原の熱帯気 候学にかんする理解と業績、ハンティントン主義的な環境決定論・人種主 義的な経済地理学への解釈などを検証し、同時に小笠原はある種の倫理的

\footnotetext{
M. Zaiki $(\bowtie) \cdot$ T. Tsukahara

Graduate School of Intercultural Studies, Kobe University, 1-2-1 Tsurukabuto, Nada-ku,

Kobe 657-8501, Japan

e-mail: zaiki@csis.u-tokyo.ac.jp

T. Tsukahara

e-mail: byz06433@nifty.com
} 
な板ばさみにあったことも、現在の国立台湾大学 (台北帝国大学) の図書館 で発見されたノートなどの新史料から指摘する。このような小笠原の業績 を通じて、折衷主義的 · 実用的と特徵付けられる日本の植民地科学の少な くとも一事例の歴史的な詳細を示すことができたと考えられる。

Keywords Colonial science · History of Imperial Universities ·

Taihoku Imperial University · History of meteorology ·

Technoscience in the Great East Asian Co-Prosperity Sphere

\section{Introduction}

After the Sino-Japanese war and the Shimonoseki Treaty of 1895, Japan acquired Taiwan as her first external territory, and claimed colonial management of Taiwan under the rubric of "scientific colonialism" espoused by Goto Shinpei. It is well known that, as part of this policy, the Taihoku (Taipei) Imperial University was established in 1928 as the first Japanese university in Taiwan, and as the sixth of Japan's Imperial Universities. The fifth of was Keijo (Seoul) Imperial University, established in colonial Korea in 1926; both were Japan's colonial universities. Those full scale colonial universities were uniquely Japanese. Scientific research at the Keijo and Taihoku Imperial Universities was generally characterized by Japan's concern for her territories. These two higher institutions were initially designed as instruments of Japan's control. At the same time, however, some local students became independent activists, and the universities became places that fostered resistance. After the colonies' independence, some science and engineering students later had a large influence on their development.

Historically, little work has been done to clarify the functions and roles of Japan's former colonial Universities in relation both to colonial management and to their effects on post-colonial techno-industrial development. Since the democratization of Korea and Taiwan, and the end of the Cold War, we have had wider access to historical resources and exchanges of information between science historians in East Asia. We have now come to a position from which we can start full-scale research on the history of science in the former Japanese colonial universities.

In the framework of science and colonialism, how should we consider the scientific activities carried out in Japan's former colonial universities? Several scholars have characterized the nature of research in the colonial setting, such as George Bassala's classic three-stage model (Bassala 1967), Lewis Pyenson's use of a three-dimensional structure to characterize different colonial exact sciences (Pyenson 1989), and Roy MacLeod's matrix on the patterns of colonial scientific practices (MacLeod 1987). ${ }^{1}$ We have observed the dispute between Pyenson by Palladino and Worboys (1993), ${ }^{2}$ and there has been much detailed case work on colonial scientists and engineers, as well as higher education institutes in colonial India, by

\footnotetext{
${ }^{1}$ See also "Introduction" by R. MacLeod, in Osiris, Volume 15: Nature and Empire. 2000.

${ }^{2}$ This article translated into Japanese by T. Tsukahara:「科学と帝国主義」、『現代思想』(Japanese journal of Revue de la Pansee d'Aujour d'Hui), vol. 29-10, 2001, pp. 144-155. 
Krishna (1979), ${ }^{3}$ Sangwan (1991) and Kumar (1992). How can we view Japanese colonial science, particularly as practiced within the colonial Imperial Universities, in this framework?

Japanese colonial science has been studied by Nakayama $(1970)^{4}$ and C. Sasaki. ${ }^{5}$ Recently, other models for understanding Japanese colonial science have been proposed, such as Kato $(1998,2001)$ and Tsukahara (2002). But these works fail to describe fully Japanese colonial science, because Japan is a "latecomer" in the already saturated colonial race, and because Japanese colonial science witnesses the integration of two factors: an imitation of Western forerunners, and a tradition of indigenous and the independent practitioners of knowledge production. Historiographically, therefore, it is necessary to see both the imperially "oppressed" aspect of Japanese science and the colonial "oppressor" aspect of Japanese scientific practice. As Bassala's transitional model shows, Japanese colonial science has particular characteristics of stages two (colonial science) and three (independent national science). In seismology, for example, Clancey (2006) argued that Japan did not just imitate Western versions, but brought about a syncretic fusion of Western science and a pragmatic response to Japan's unique Eastern studies on geographic, seismographic and cultural conditions.

This paper intends to develop Tsukahara's and Clancey's points about “doublesided" Japanese colonial science, with a case study of Taiwan, by studying meteorological science at the Taihoku Imperial University. We intend to demonstrate how these two aspects syncretized and produced the special characteristics of academic works in colonial Taiwan. Moreover, we empirically examine scientific activities in terms of the broadly defined concept of "scientific colonialism." To do that, we will look closely at the work of meteorologist Ogasawara Kazuo at the Taihoku Imperial University, which had a department of meteorology set up to pursue weather forecasting, military strategy, and planning for plantation management. As a scientific discipline, meteorology fitted the colonial character of Japanese expansion to the south, because it encompassed aspects of both exact and applied science, from its basis in atmospheric physics to its extension of geographic climatology. Also, meteorology describes a wide range of scientific practices, which include day-to-day local observations, as well as the process of institutionalizing meteorological institutions, which culminated in the bureaucratic centralization and networks centered on the Imperial Capital, Tokyo.

In order to understand this historical background, we will first review how Japan's overseas meteorological network was organized in Japan's former colonial empire. We will then discuss the corresponding institutionalization of meteorology during that period.

\footnotetext{
${ }^{3}$ Krishna's argument was re-interpreted in Japanese context by Y. Kakihara: 杮原泰、「近代日本の工学 教育における科学と実地の相克：工部大学校における電信工学 (Conflict between science and practice at engineering education in modern Japan)」、『年報科学 · 技術 · 社会』 (Annals of Scence, Technology and Society), vol. 5, 1996.

${ }^{4}$ Nakayama discussed this issue, even before Bassala's work in 1967 (Nakayama 1965).

${ }^{5}$ C. Sasaki's article on the amendment of Pyenson is included in Science and Empires, P. Petitjean and C. Jami, eds., 1992, Paris.
} 
We will see that Ogasawara's career began as a pure scientist and shifted to service for colonial management, as he justified Japan's expansion into the south, even as far as Australia and New Zealand. By doing this, we can demonstrate Japanese colonial science's pragmatic nature, in response to requests by army strategists. Ogasawara's mixed attitude toward an American meteorologist then in Manila, Charles Deppermann, will also be described using newly discovered notes now kept in Taiwan National University's archive. Our argument is that Ogasawara's dilemma can be considered a typical psychological problem that scientists on the war front faced. As a racial geographer, Ogasawara proposed Huntingtonian environmental determinism, in that we see an illustration of Japan's Imperial science as a modification of European practice, and as a justification of Japanese expansionism.

\section{Japan's Colonial Meteorology: Meteorological Observation Network}

Just a year after Japan's occupation of Taiwan in 1895, temporary observatories were established in strategic locations all over the island (Fig. 1). The army was given charge of these observatories, whose expected function was to issue storm warnings. The army's involvement in meteorological operations resulted directly from the Sino-Japanese War, which had just ended. Soon after, these temporary observatories were re-organized into the Imperial meteorological network, centered at the Central Meteorological Observatory (中央氣象台: $\mathrm{CMO}^{6}$ ) at the "Imperial Metropolis Tokyo" (Teito Tokyo: 帝都東京). The operation of these institutions was gradually re-organized from military to civilian control, and towards the creation of a bureaucratic network centered in Tokyo. This centralization of meteorology depended on the establishment of other modern infrastructure, such as the telegraph and submarine cables, and railway networking.

Wada Yuji (和田雄治: 1859-1918) ${ }^{7}$ was a key person in the early institutionalization of meteorology in Tokyo. He was chief of the CMO's weather forecasting division and wrote a paper in 1895 (Wada 1895) regarding the importance of forecasting typhoons, showing that those passing Taiwan may reach mainland Japan.

At the time, Goto Shinpei (後藤新平: 1857-1929) had claimed a general policy of "scientific colonialism" in Taiwan. Goto's concept of "scientific colonialism" can be considered a uniquely Japanese concept, because he defined neither science nor colony rigorously, but rather pragmatically used both terms for the management of Taiwan. This scientific method was directed to geographical research, and to the application of useful Euro-American tools for colonial development. For him,

\footnotetext{
${ }^{6} 1887-1856$. The predecessor of Japan Meteorological Agency (JMA , 1956- ). The CMO was called the Tokyo Meteorological Observatory (TMO) between 1875 and 1887.

${ }^{7}$ Wada later became a director of the observatory in colonial Korea. He is also known for his historical climatological research in Korea, see Miyagawa (2006). Also, Miyagawa continued to work on Wada, at Seoul, and his recent results are presented as follows: Takuya Miyagawa (Seoul National University, Korea),"Building the Meteorological Observation System and Colonial Meteorology in the Early 20thcentury Korean Peninsula by Imperial Japan", presented at the 2007 winter International Workshop of Japan's former Imperial Universities, "History of Science on the Keijo Imperial University: Its knowledge production and legacy", held at Waseda University \& Aoyama Gakuin University, December 19-20, 2007, Tokyo.

型 Springer
} 


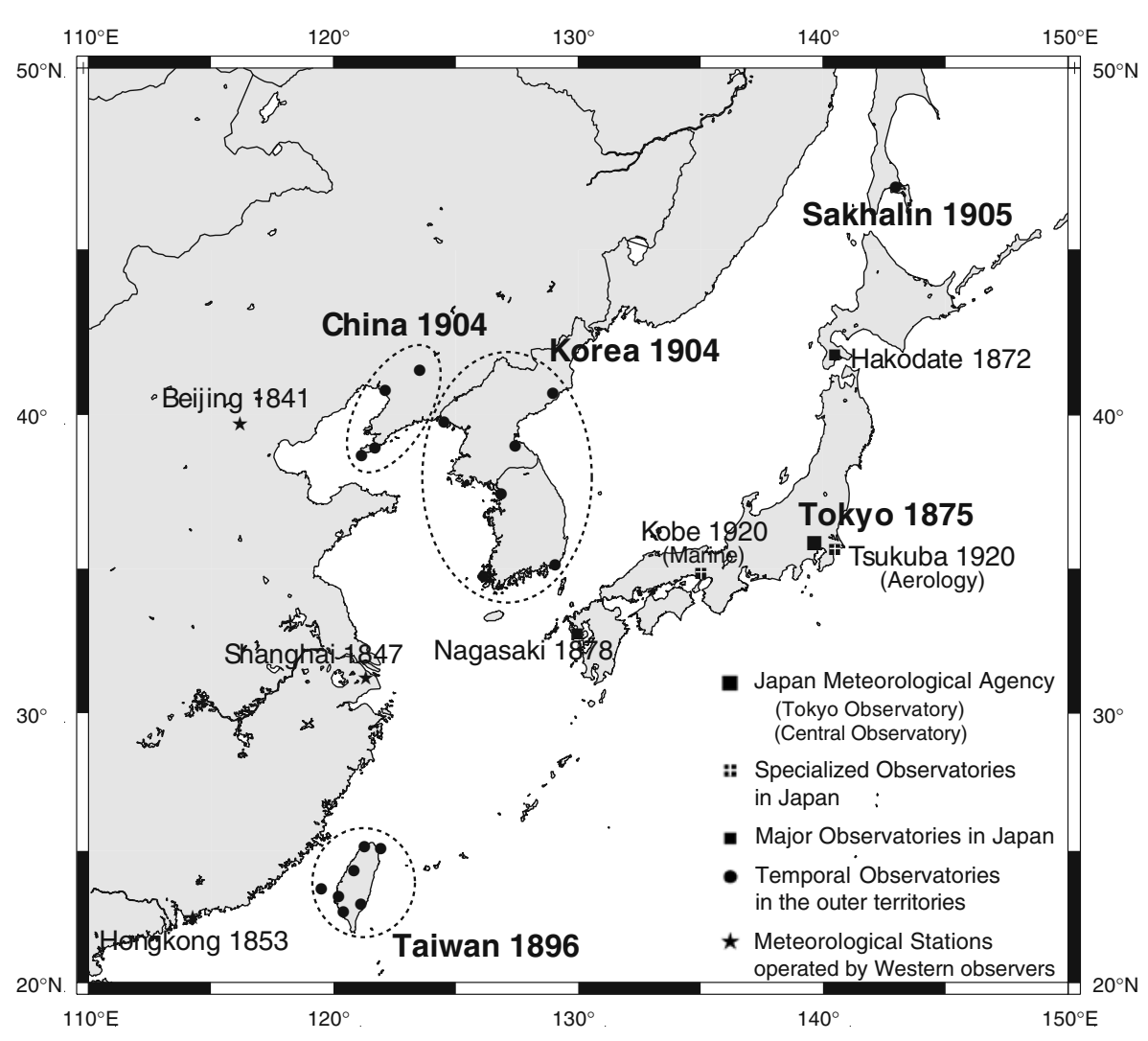

Fig. 1 Map indicating locations and establishment years of the Japan Meteorological Agency, specialized and major Japanese observatories, temporal observatories in the outer territories, and other meteorological stations in East Asia

demographic/geographic statistics seemed the most important "science"; the exploration of every corner of Taiwan was organized under his initiative.

Medical historians and medical sociologists argue that under Goto's initiative, socalled "hygienic modernity" of Taiwan was introduced. Actually, by his initiative, several expeditions were successfully and "scientifically" organized with big budgets, led by Goto himself across the whole island. Goto is known for favoring the establishment of research sectors in the bureaucracy, was later appointed as the Mayor of Tokyo City after the Great Earthquake and president of the Manshu Railway, and his mission was to design and oversee Japan's advancement to the continent. We should therefore understand the definition of "science" in colonial management as Goto practiced it, not in terms of our contemporary understanding of "exact science," "applied science" or the "institutionalization of science." In Goto's sense, "scientific colonialism" referred to any useful application of knowledge, most

\footnotetext{
${ }^{8}$ For the concept of "hygienic modernity," see Rogaski (2004). We should note that Rekishigaku Genkyu (Journal of Historical Studies) featured a special issue to examine the conception of colonial modernity from the view point of history of medicine in colonies in the last issue of no. 834 in November 2007.
} 
of which was derived from Western science. It is not our task to criticize Goto's ambiguity in defining "science"; our purpose is to see the historical process, and show how Goto and his followers in the Japanese colony practiced "science" in Goto's colonial framework.

In the process of exploration and geographical research in the new colony, meteorology was considered one of the essential practices of scientific colonialism; the establishment of meteorological observatories was placed high on Goto's agenda. ${ }^{9}$ No wonder, therefore, that such practices would later effect the establishment of the first independent department in the subjects of Japan's Imperial University. We see the colonial character of meteorology, that this took place at this colonial university in Taiwan, not at other Imperial Universities on the mainland.

In meteorology, Japan has had a peculiar development pattern. Before the establishment of an independent department of meteorology in Taiwan, the earliest institutionalization of a meteorological observatory was at Hakodate, in Hokkaido (Ezo), in 1872, even before the establishment of the Central Observatory in Tokyo in 1875. As Tsukahara has pointed out (Tsukahara 2006a), ${ }^{10}$ the colonization of Hokkaido was the driving force behind this early institutionalization, and the American military was concerned with these new Japanese northern territories, mainly through the agency of General Ulysses Grant's team of the advisers to Japan's newly established Meiji Government's Office for Hokkaido Development (Hokkaido Kaitakushi 北海道開拓使).

Japanese colonialists also tried to apply agricultural techniques under the policy of "scientific colonialism". As we can see, Goto's concept of "science" included anything useful from the West. The most notable introduction of modern agricultural methodology to Taiwan was carried out by Nitobe Inazo (新渡戶稻造: 1862-1933). Nitobe was an important historical figure in Japan because he was one of the early modernizers, and was a Christian. Formerly, his picture was on the Japanese currency, on the second most valuable (5,000 yen) note, after Fukuzawa's 10,000 yen. Nitobe was more than an Enlightenment modernizer and a instrument of the Christian missionaries; he was also an excellent colonial agricultural/agronomical designer. Goto asked NItobe to develop a sugar plantation for Japan's new colony, and to scientifically colonize Taiwan with Western style colonial plantations. Trained at the Sapporo Agricultural Institute in Hokkaido, which was supported by American scientific advisers, Nitobe was familiar with American-style agriculture, and meteorology and climatology were also part of his scientific methodology. We see here that Japan's northern and southern peripheries worked together closely, and that the successful model of American colonial agriculture was efficiently applied to the southern colony.

Wada's colleague, Nakamura Kiyoo (中村精男: 1855-1930), the most notable meteorologist of the time and head of the CMO, appointed Kondo Kyujiro (近藤久

\footnotetext{
${ }^{9}$ Zheng discussed the Japanese expedition related to Taihoku Imperial University in her Ph.D. thesis; see 鄭麗玲, 『帝国大学在植民地的建立與発展：以台北帝国大学為中心』, 2001 年, 台湾師範大学博 士論文.

${ }^{10}$ For history of meteorology and historical resources of Japanese climate, see Zaiki et al. (2006). 
次郎: $1858-1926)^{11}$ as director of the Taipei observatory in 1896. Kondo investigated not only the climate in Taiwan, but also earthquakes and volcanic activity (Kondo 1917; Kondo and Teramoto 1918). Some early research on Taiwan's climate was also carried out during this period. ${ }^{12}$

The second director, Teramoto Sadakichi (寺本貞吉), succeeded Kondo and published works on higher atmospheric meteorology on Mt. Ali in $1925 .{ }^{13}$ An aerological observatory on Mt. Ali was founded, and scientific research in Taiwan corresponded with advanced meteorological research abroad and in Japan.

In 1932, Nishimura Denzo (西村傳三: 1893-1969) ${ }^{14}$ was appointed third director by Okada Takematsu (岡田武松: 1874-1956), ${ }^{15}$ the director of the CMO. Both Nishimura and Okada were actively engaged in research on meteorology and climatology. At the same time, a bureaucratic system that supported meteorological practice was also established within the local colonial government, such that the Taipei Meteorological Station (臺北測候所: TMS) became the Taiwanese GovernorGeneral's Observatory (台灣總督府氣象台: TGO).

However, there was continuous tension between the military and the bureaucracy over the meteorological observatory's position. The Russo-Japanese war in 1905 gave the Japanese a chance to advance through the Korean Peninsula. More temporary observatories in Japan's outer territories (外地) were founded in Korea and China in 1904, and in Sakhalin in 1905. As in Taiwan, those observatories were gradually adopted by the colonial management system. In Korea, they became part of the Korean Governor General's Office; in China and the Manchurian territories, they became part of the Kanto-State General Office; and on the island of Sakhalin, they come under the supervision of the Bureau of Karafuto (樺太廳).

\section{Academic Approaches to Meteorology}

\subsection{Internal Development and Corresponding Institutionalization}

We would like to discuss the merits of historical research into meteorology in the colonial setting. Meteorology is a scientific discipline that reaches from basic/exact science to applied/institutionalized science. In practice, its cultural context is reflected in the content of its knowledge production, and its research strategy has been economically/politically determined. Different actors at different levels, from

\footnotetext{
${ }^{11}$ The period of Kondo's engagement in Japanese meteorological observatories is 1881-1925.

${ }^{12}$ See such works as Kondo (1899).

${ }^{13}$ S. Teramoto, 阿里山的氣候 (Climate in Mt. Ali), ca,1932, Taiwanese Governor-General Observatory.

${ }^{14}$ The period of Nishimura's engagement in the Japanese meteorological observatory in Taiwan was from 1923, so he had a longer career in Taiwan than other directors. He was seemingly respected by locals; there were some memoires by local meteorology engineers and observatory staff. It was probably because he spent a longer time in Taiwan and fostered local meteorological engineers, and because he was promoted up the local bureaucratic ladder, not directly appointed from the center.

${ }^{15}$ Okada was one of the most well known meteorologists, and an influential scientist in public affairs since he was also known as a popular science writer. Okada engaged in Japanese meteorological observatories between 1899-1941.
} 
metropolitan scientific journals to military strategists, or from seismological mechanics to agronomical climatologists, can get involved in the "trading zone" of meteorology. ${ }^{16}$

In the period with which we are concerned, there were two emerging fields in meteorology in the Euro-American scientific community. Meteorology's scientific frontiers had two physical extensions: marine meteorology and aerology. Marine meteorology was also practiced as a part of oceanography, and aerology as a part of atmospheric physics. Japanese meteorologists were eager to catch up with Western academia.

In the scientific culture of Japan through the first quarter of the century, physics was the leading science. Nagaoka Hantaro (長岡半太郎: $1865-1950)^{17}$ was, for the first time, gaining international recognition in pure/exact science for his atomic structure model. Together with Nagaoka, some other leading physicists also showed an interest in meteorological approaches, and in 1912 the Meteorology Discussion Group (氣象學講話會) began meeting regularly in Tokyo. This group also included such celebrated figures as the physicist Terada Torahiko (寺田寅彦: 1878-1935) and the famous applied physicist, also known as the early science journalist and scientistessayist of the time, and seismologist Omori Fusakichi (大森房吉: 1868-1923). From basic and applied physics to seismology, we see close cooperation among the leading members of the Japanese scientific community, and that it was centered on meteorology. The physics of atmospheric phenomena, aerological research into the atmosphere's upper layer using balloons (Radio-Zonde), was the commonly intriguing topic for them.

One of the formative members of the Meteorology Discussion Group, Oishi Wasaburo (大石和三郎: 1874-1950), ${ }^{18}$ a chief in the CMO's department of forecasting, made a research trip to Europe. In Germany, he was impressed by marine meteorology at the Hamburg Marine Observatory, and by aerology at the Lindenberg Aerological Observatory. After his return to Japan, he shared his new knowledge with his colleagues, and promoted the establishment of institutions for marine observation and aerology. He obtained the support of the navy and the army, both of which were well aware of these institutions' strategic importance, and succeeded in establishing research institutes for both marine meteorology and aerology.

\footnotetext{
${ }^{16}$ To see scientific discipline as a "trading zone", we owe this idea to Sean Hsiang-lin Lei, and to his oral presentation at the Kobe 2002 East Asian STS Symposium, "Building a Taiwanese STS Network: History, Strategy and Challenge", where he paraphrased STS as "transactional space", using Pieter Galison's framework. For P. Galison's concept of "Trading Zone", see Galison (1999). Also, Chu Pingyi's analysis of a Japanese chemist Nozoe Tetsuo at Taihoku Imperial University gave us stimuli to employ this concept in our discussion. Chu's oral presentation was given at the East Asian STS Symposium at Seoul, 2004, and his presentation title is "Struggle in Periphery: Nozoe Tetsuo and Japanese Colonial Science in Taiwan".

${ }^{17}$ Nagaoka was a professor of physics at Tokyo Imperial University, and became known for the NagaokaRutherford model of orbital structure atoms. Nagaoka's physics is usually known as the landmark of "independent science" in Japanese, in Bassala's model.

${ }^{18}$ About Oishi, see Lewis (2003).

望 Springer
} 
The year 1920 was thus a remarkable point in the history of Japan's meteorology, with the establishment of both the Kobe Marine Observatory ${ }^{19}$ and the Aerological Observatory in Tsukuba, as Oishi proposed. Oishi was appointed director of the Aerological Observatory. The establishment of these research institutions was then called “the system of the three research institutions"(三研究所体制), centered on the CMO in Tokyo, Aerology in Tsukuba, and Marine Meteorology in Kobe. The establishment of these three research institutions corresponded to the concept of Imperial space, centered in Tokyo, which spread to the Pacific Ocean from Kobe and to viewing the sky from Tsukuba. An institutional base for the practice of meteorological research in the Great Japanese Empire (大日本帝国) was thus inaugurated. Further stepping stones to the continent were found at Keijo (Seoul, Korea), and in the southern territories at Taihoku (Taipei, Taiwan), where the Japanese placed Imperial Universities in 1926 and 1928, respectively. The 1920s can thus be understood as the time of the formation of an Imperial space of Japan for the gaze of meteorology.

In sum, it is clear that personal visits to European scientific institutions became momentous for the development of the sciences in Japan. This represents the typical catch-up dynamic. Also, Japanese sciences were becoming more influenced by German science, and were supported by military factions. Aerology was inspired by aviation strategy, which began in World War I, and marine meteorology by navy strategists.

\subsection{Establishment of Imperial Universities}

In the process of institutionalizing science in Taiwan, the Taihoku Imperial University (台北帝國大學) was established in 1928, with two faculties: Literature-Politics (文政学部) and Agriculture-Science (理農学部). The department of meteorology was included as one of the first six departments of the latter faculty. This was the first Japanese university with an independent department of meteorology. Until this time, meteorology had been a sub-discipline of Agriculture (i.e., agricultural meteorology) or physics (i.e., atmospheric aerodynamics, or geophysics/seismology). Taihoku Imperial University was originally designed for "scientific colonialism," and meteorology was meant to serve colonial purposes.

As Tsukahara (2006b) discussed, the establishment of the nine Japanese Imperial Universities was closely related to Japan's territorial expansion. The Kyoto, Tohoku and Kyushu Imperial Universities were established in the aftermath of the SinoJapanese and Russo-Japanese Wars (Fig. 2). The Imperial Universities' missions were decided according to the prevailing political agendas. Although Keijo (Seoul) and Taihoku Imperial Universities were also seen as the products of local demand for higher education, the colonial universities were considered to be knowledge

\footnotetext{
${ }^{19}$ Originally, the Kobe observatory was a temporary station, as a branch of the Osaka Observatory, and was reformed into the Kobe Marine Observatory by 1920 central governmental regulation. The Aerological Observatory was newly built in Tsukuba (in Ibaragi Prefecture, at the north of Tokyo, where Tsukuba University is now situated), and started operating its scientific practice in December of the same year.
} 
Fig. 2 The Nine Imperial Universities and Japanese modernization

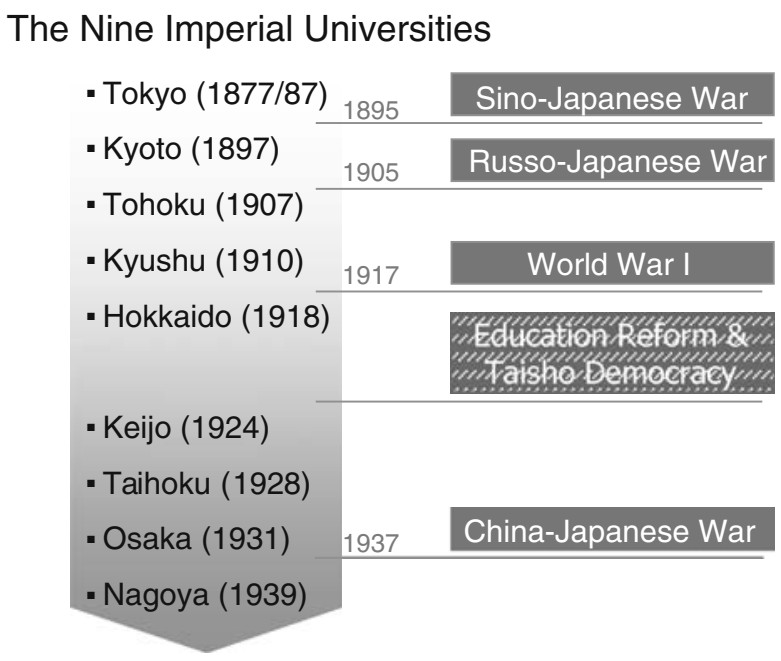

production centers for the northern frontier at Keijo (Seoul), and for the southern frontier (Pacific/tropics) at Taihoku.

In the following sections, we take a closer look at meteorological works and a specific colonial scientist, in order to demonstrate the character of Japan's colonial science.

\section{A Scientist in the Colony: Ogasawara Kazuo at Taihoku Imperial University}

\subsection{Ogasawara Kazuo as a Colonial Scientist: from Physics to Weather Forecasting}

Ogasawara Kazuo (小笠原和夫: 1899-1979) was appointed Associate Professor at Taihoku Imperial University under Professor Shiratori Katsuyoshi ${ }^{20}$ in 1929 . He was born in Yamagata Prefecture in $1899,{ }^{21}$ and studied at Kyoto University, ${ }^{22}$ and was appointed to Taihoku in 1929. His earlier works were mostly on electricity in the

\footnotetext{
${ }^{20}$ Shiratori Katsuyoshi (白鳥勝義) was a professor at Taihoku Imperial University and was originally trained as a physicist. Before coming to Taiwan, Shiratori was a lecturer in Earth Physics at Tohoku Imperial University. After his appointment at Taihoku Imperial University, he established the Society of Taiwan Meteorological Research in 1929, and the Society of Agricultural Meteorology in Japan in 1942.

${ }^{21}$ Yamagata Prefecture is an agricultural area located in the eastern part of northeast Japan, and considered a backward area, sometimes even affected by famine in years of poor harvest.

${ }^{22}$ According to his notes, kept in the Aoki Collection at Taiwan National University, he disliked the student culture of Kyoto, and was not at all attracted to the then popular Marxism and liberalistic discourse. Instead, he was inspired by the Practical Studies (実學思想) of the agronomist-conservative philosophers Sato Nobuhiro (佐藤信淵) and Kumazawa Banzan (熊沢蕃山) of Edo period. From his experience, he argued that Marxism would never be able to solve the problems of poverty in an agricultural society in need, but he believed in "Practical Studies." For him, such scientific approaches as long-term weather prediction would be the only suitable countermeasures to avoid famine.
} 
atmosphere, written in English even in the 1930s. ${ }^{23}$ This mode of writing was considered best to address European-American scientists; he wrote not only in English, but also submitted his works to German journals, such as Gerland's Beitrage. In his early career, he was a normal practitioner of exact science, conservative, stayed away from the liberal student culture, and retained idealistic views of science for the sake of human welfare.

We do not yet have any empirical evidence for why he did so, but he then shifted his focus from physics to weather forecasting in the Philippines. He must have received a command from the military to carry out this research mission. In order to fulfill this task, Ogasawara scrutinized the field's authority, Charles Deppermann's works on weather and climate in the Philippines, and between 1941 and 1945, Ogasawara published almost all of Deppermann's works in a 10-volume Japanese translation. $^{24}$

We have still to look more closely into his motives, and the institutional structure behind this shift in research focus, to see whether there was a specific demand to do so or any form of command from the military sector and/or the Colonial Government to forecast the Philippines' weather. Ogasawara's personal archive is dispersed, and historical research has yet to reach military documents on meteorology in Taiwan. But at least we see that the change in his mode of research was drastic: from firsthand and original research to a second-hand translation. In other words, the change is from the "pure science" of atmospheric physics to the "applied science" of weather forecasting. As an academic strategy to gain recognition, he did not carry out "curiosity-driven" work of his own, or the German idealist's scientific practice of "knowledge for its own sake," but carried out "problem-solving" for someone else and sought "knowledge that contributes to some purpose." 25 His audience changed from that of cosmopolitan academics and journal referees to local and colonial Japanese readers.

\footnotetext{
${ }^{23}$ "The Effect of Temperature and Water Vapor on Diffusion-Coefficients of Ions in Air," Memoirs Faculty of Science and Agriculture, Taihoku Imperial University, vol. XVIII, no. 6, Meteorology and Geophysics, no. 4, Nov. 1936; Local Variation of Atmospheric Potential-Gradient Measured at Taihoku, Formosa, Terr. Magn. and Atm. Electr., March 1940; Electrical Polarization and Field Intensity in the Atmosphere, reprint of Institute of Meteorology and Geophysics, Taihoku Imperial University; The Local Variation of Atomosperic Potential of Gradient During Solar Eclipse at Taihoku, Gerland's Beitraege, vol. 56, p. $203 \mathrm{ff}, 1940$.

${ }^{24}$ This translation is titled, Materials for Weather Forecasting in Southern Sea (南方氣象預報資料), (published in Taihoku (Taipei), Taiwan), and the English titles are attached as follows: The First Book, Preface; The Second Book, Outlines of Philippine frontology; The Third Book, The mean transport of air in the Indian and South Pacific Oceans; The Fourth Book, Are thunderstorms around isolated island stations in the Philippines frontal?; The Fifth Book, Typhoons originating in the China Sea; The Sixth Book, Typhoons and depressions originating near east of the Philippines; The Seventh Book, Some characteristics of Philippine typhoons; The Seventh Book, Upper air in Manila; The Eighth Book, The weather and clouds of Manila; The Ninth Book, Upper air circulation (1-6 km.) over the Philippines and adjacent regions; and The Tenth Book, Discussion of results of soundings of temperature and humidity at Jhikargacha (Bengal) in April and May 1929, by Chatterjee, G. and Sur, N.K. Those are credited as "Originally Written by Dr. Deppermann," and are translated with explanations by Kazuo Ogasawara.

${ }^{25}$ The difference in scientific practice between "curiosity-driven" and "problem-solving" is characterized in categories by Ziman (1994) and Murakami (1994).
} 
For us, an interesting episode in Ogasawara's life concerned an American scientist in the Philippines that we have newly discovered in several of Ogasawara's notes. Ogasawara's counterpart in the Philippines, Charles Deppermann, was a Jesuit meteorologist and the Assistant Director of the Philippine Weather Bureau. Depperman was already known as the authority in the field, and Ogasawara needed his help to carry out his mission.

In 1942, Ogasawara visited Manila and asked for Deppermann's research cooperation, which was given and Ogasawara was welcomed as a fellow scientist. Deppermann did not behave as an enemy American, but patronized the younger scientist from Japan. Ogasawara met Deppermann in person for the first time in Manila. Without reservation, Deppermann helped Ogasawara in his research on Philippine weather and climate, to the extent that Ogasawara left Deppermann a special note of gratitude in his works. ${ }^{26}$ Ogasawara's personal notes show that he felt honored and treated as a friend of science by the highly respected Deppermann.

We must recall, however, that 1942 was a difficult year for both men. Following Japan's attack on Pearl Harbor in 1941, the Americans were fighting back in the Pacific. It is more than obvious that Ogasawara had taken on a mission to carry out strategic research on the weather patterns of the Philippines during his visit. In spite of this, Deppermann helped him in the name of science and shared academic interests, granting Ogasawara access to the research materials kept in Deppermann's school, the Ateneo de Manila.

This collegiality fostered in Ogasawara severe moral dilemma. In Ogasawara's post-1942 publications, Deppermann wrote several prefaces and forewords. One of these forewords is a reprint of a letter from Deppermann to the Bulletin for the American Meteorological Society (Feb. 1941), entitled "Publication of Kazuo Ogasawara on Formosan Meteorology."27 Deppermann wrote,

"We wish to call attention to the work of Kazuo Ogasawara, which may be of some interest to readers of the Bulletin. ...All these papers are in English and we feel sure reprints would be very gladly sent by Professor Ogasawara to any who may request them. He is still actively engaged in further meteorological and climatological researches, principally along Norwegian lines."

Another is an invitation to the seventh Pacific Science Congress in 1941 from B.M. Gonzales, Chairman of the Organizing Committee, to the President of Taihoku Imperial University, Mita Sadanori, d.d. April 16, 1941. It mentions, "Rev. Fr. Charles E. Deppermann, S.J., Secretary of the Committee on Meteorology and Climatology, would like to invite particularly Professor Kazuo Ogasawara of the Institute of

\footnotetext{
${ }^{26}$ Ogasawara openly expressed a very high regard for Deppermann as a scientist, and called him as a great teacher in the prefaces of some of his works; a whole translation series was dedicated to Deppermann. Ogasawara described Deppermann as a benefactor for his work in the field, and remarked that, without his help during his visit to the Atheneo de Manila in 1942, the core of his work would have been missing. ${ }^{27}$ Those notes are attached to Preface to Material in a rather random way, as entitled「南方気象予報資 料」,「序説」,「序文 並びにデッペルマン交 遊録」. Also in his book, 「南方気候論」, Publications of Kazuo Ogasawara on Formosan Meteorology, there are two-page abstracts. This is a citation from Bulletin of the American Meteorological Society, Vol. 22, p. 75, Feb. 1941.

iㅡㄹ Springer
} 
Meteorology and Geophysics to attend and read scientific papers at the said Congress."

It is strange to attach such letters to scientific works, but Ogasawara read them as signs of recognition from Western-metropolitan scientists, a prestigious endorsement, which he hoped to share with his audience.

In Ogasawara's later publications in 1945, however, he wrote that he was reminded of the words of Louis Pasteur: "Science has no border and nationality, but scientists have their own nation." 28 Ogasawara claimed that, even though Deppermann was a respected master, Japanese science should forget him. He was an American and would inevitably take the enemy's side. Ogasawara wrote,

"Now, Deppermann has become a Japanese war captive under Japan's occupation of the Philippines, and he is leading his life of religious confinement as a prisoner; but for me, it is necessary to shut out any former human relationship with him. What our scientists should do is to work for a much better meteorology than that of Deppermann and the Bergen School, and we should devote ourselves to establishing a Japanese meteorology. The supreme moral is to progress the holy war by the Imperial Nation of Divinity. It is in this way that holy war cannot conflict with the principle of science, at all."29

These are rather embarrassing remarks, especially as they were written in 1945, the worst time for the Japanese. Still, Ogasawara's publication was dedicated to Deppermann and we can see some of the conflicting moral forces pushing him: the idealistic concept of the universality of science, the limitation of scientists as national servants, and the respected master who is taking the side of an enemy. Ogasawara must have been bound to the Confucian moral value, which obliged him to pay due respect to his own teacher under any circumstances. ${ }^{30}$ To have mentioned Deppermann in his dedication seems an apologetic in this context. ${ }^{31}$

We may interpret Ogasawara's moral position not only as reflecting his colonial situation, but also as representing the conflicting nature of Western and Japanese science. Ogasawara's dilemma can be considered as a typical illustration of the double-sidedness of Japanese science. In order to synthesize the value of science and national goals, he felt a guilty consciousness, under the doubly binding obligation to respect his teacher and denounce his enemy.

\footnotetext{
${ }^{28}$ Reference to Deppermann, seen in a proof print entitled “Famine and Weather," (「気象学通論とデッペ ルマン博士」,「凶作と気象」, 1945).

${ }^{29}$ Ibid.

${ }^{30}$ Ogasawara's respect for his teachers and seniors is expressed in his work, "Famine and Weather," 1944. (小笠原,「凶作と天候」 (S.19) の中表紙) His humble attitude toward nature and science, and his gratitude for Deppermann, were expressed in 1942, in 南方気象予報資料 no. 10. s.17 年, 10 月.

${ }^{31}$ Later, however, the situation became more complex. After Japan's defeat, the position was over-turned. The details are unknown, but one of Ogasawara's students remembers that Ogasawara relied on Deppermann again, because he helped Ogasawara after the war. Deppermann wrote a letter asking for an exemption in order for Ogasawara to avoid being persecuted as a war criminal, based on his meteorological collaboration with Japan's warring mechanism. This might have been a source of shame for Ogasawara; we need a more detailed examination of this.
} 


\subsection{His "Climatology of the Tropics"}

We would like to illustrate one more case showing that Japanese cultural synthesis was not simple. As a Japanese scientist, Ogasawara was doubly bound between an inferiority complex towards Westerners and claim for the racial superiority of Japan. As Gregory Clancey has discussed, Japanese science was a fusion of Western science and local practice. However, in the discourse of science, science was not confined within the technical/exact scientific sphere, but Japanese sciences combined ideological aspects of Western science, such as racism, ethnic-geography and climatological determinism, into the Japanese Imperial ideology.

In Ogasawara's work, he elaborated extensively on the tropical climate, and published Climatology of the Tropics (南方氣候論) in 1945 (Ogasawara 1945). This is an informative work of 360 pages with many tables, maps and graphs, consisting of three major parts, with three appendices. ${ }^{32}$ The book covers the climate of the southern part of the Great East Asian Co-Prosperity Sphere, namely, from Taiwan to the Pacific, and also the Oceania region. The book illustrates Ogasawara's view of the tropical climate and some characteristics of colonial meteorology. It also highlights his interpretation of Huntingtonian climatological determinism.

The first part includes a general discussion of climatology and meteorology, alongside the most advanced Norwegian-American school of Bergen, led by $\mathrm{V}$. Bjerknes. Ogasawara cites from the Manila school by Deppermann and explains the theory of air mass (気団論) and the cause of low pressure (低気圧発生論). In the framework set by Bjerknes and Deppermann, he provides his explanation of the tropical climate, including its seasonal winds and squalls, its characteristics of rainfall and fog, and other meteorological phenomena. In sum, Ogasawara utilized the most advanced framework available and interpreted it for the regions with which he was concerned. This was an accumulation of an individual's effort to catch up with metropolitan scientific theory.

The second part describes botany and climatology. This is an overview of local vegetation, with special reference to food supply and the possibility of plantation agriculture. This was meant as a guideline for military strategists on colonial management.

The third part includes detailed climate descriptions of Indo-China, Thailand, Burma, the Philippines and Malaysia. This part also discusses the Dutch East Indies, Sumatra, Borneo, Celebes and Java, as well as New Guinea and its neighboring archipelago. For instance, Ogasawara first divides Java's climate into three areasWestern, Central and Eastern Java - and gives general descriptions of each, such as average temperature and humidity tables, maps of monthly rainfall totals for different locales, sunshine percentages according to height from sea level, and specific vegetation and botanical features.

\footnotetext{
${ }^{32}$ Some chapters and proof printings are kept in the National Taiwan University Library, in the Aoki collection. Aoki was a former Dean of the Agriculture-Science Faculty at Taihoku Imperial University, so we can trace the long preparation before the final publication in 1945. Thanks to Wu Chia-Ling and her colleague's help at National Taiwan University, we had access to this material, and now can shed new lights on so far unknown aspects. To open such access to historical mateiral is one of the results of East Asian STS networking. 
As a whole, this work gives an integrated view of climate in the southern frontiers of Japan's Empire, which included notes on the future possibility of agronomical management under the Japanese Empire. But, what was this work's scientific originality? Once we take a closer look at the sources, we see that most of the data were based on foreign resources. For example, in the chapter on Java for the Dutch East Indies, he drew up original sources from European literature, such as F.A. Miquel's classic work written in Dutch, Flora van Nederlands-Indie (1855-1859), and later works published in German in Vegetationsbilder, such as articles in German by Rutten, "Die Wasservegetation einiger Seen Niederlandische-Indies" (1940), and by Domin, "Vegetationsbilder aus Java, vorwiegend aus den Urwaldern der westjavanischen Vulkane" (1913), and an English article, Seifriz's "The altitudinal distribution of plants on Mt. Gedeh, Java" (1923). ${ }^{33}$ Elsewhere, his method was more or less the same: with an amazing linguistic capability, he collected useful information written in many European languages, and accumulated them into his book.

By present standards, Ogasawara relied mostly on secondary sources, and his original contribution was less noteworthy, but his work was not aimed at satisfying scientific priorities, but at presenting climatological descriptions to a Japanese Imperial audience. His book was sufficient for that purpose.

\subsection{Ogasawara's Understanding of Huntingtonian Racial Climatology}

In his book, Ogasawara attached three appendices on specific topics. The first was on colonial agriculture in the Southern Co-Prosperity Sphere, ${ }^{34}$ the second on hazards posed by locusts in the Philippines and Taiwan, ${ }^{35}$ and the third on the climate of the Southern Co-Prosperity Sphere (南方共榮圈). ${ }^{36}$ The first and third are clear expressions of colonial policy-making and his understanding of tropicality and geopolitics.

Ogasawara despised life in the tropics. In his lectures at the Okayama Medical College in 1944, published as the third appendix, he argued that the tropical climate would degenerate ethnic quality. He argued that government should strictly maintain the Japanese lifestyle abroad in the face of the harsh tropical climate, which could erode Japanese ethnicity. For this argument, he cited a work of his colleague, Seiichi Iwao (岩生成一: 1900-1988), a professor of southern sea history (南洋史) at the Taihoku Imperial University. ${ }^{37}$ This proved an interesting collaboration between seemingly unrelated disciplines. Iwao is famous for his analysis of Japan's southern emigrants since the fifteenth century (Iwao 1941), who were known as pirates, which helped to create early stereotypes of Japanese as violent savages. However, some successful pirates received royal permission to form an enclave in Thailand, and for

\footnotetext{
${ }^{33}$ This work is claimed to be published in the Bulletin of Torry Botanical Club (Linnean Society).

${ }^{34}$ Original title: 附録I, 南方共榮圈の死産氣候論, pp. 295-306.

${ }^{35}$ Original title: 付録II 温雨図の利用 : 比律賓飛蝗と台湾との関係 (気候生態学的考察),pp. 307-318.

${ }^{36}$ Original title: 附録III 南方共榮圈の氣候学的条件, pp. 319-336.

${ }^{37}$ About the department of Southern Sea History as a characteristic discipline at Taihoku Imperial University, see Wu (2005).
} 
some generations this Japanese enclave had prospered. Their success, as interpreted by Ogasawara, was a result of Japanese ethnicity. He was obviously proud of these early Japanese, despite the fact that most of them lived by piracy and were disliked by the locals. Ogasawara tried to frame these early emigrants as the forerunners of his contemporary Empire.

Ogasawara went further, suggesting that in order to overcome ethnic degeneration, a Japanese "Co-Prosperity Sphere" should include Australia and New Zealand, which, he claimed, were most suitable for a Japanese colony. Advancement into the southern region was therefore justified as a process of acquiring those areas.

Ogasawara also referred to Ellsworth Huntington's works on racial geography. ${ }^{38}$ Huntington was an economic geographer, known for his environmental determinism. ${ }^{39}$ He had served as the President of the American Eugenics Society, and had justified colonialism and white dominance. Huntington's Climate and Civilization (1915) discussed racial geography, and presented a map displaying degrees of civilization (Fig. 3a, b). On Huntington's map, in accordance with the principle of "Equatorial Paradox," 40 distance from the equator indicates a civilization's development; thus Europe and North America are the most suitable areas for civilization. The northeastern part of the United States, Western Europe and southeastern Australia are ranked as the most civilized areas. Japan and East Asia are ranked as second- and third-tier civilizations.

How should the Japanese, fighting against Western dominance, react to such white racism? Ogasawara's mixed views were that he modified Huntington's presentation (Fig. 4a, b). When we compare the two, we see that Ogasawara upgraded mainland Japan's degree of civilization from second-tier to first-tier, Korea is placed in the second tier, and Hokkaido (originally inhabited by the Ainu people), Manchuria and Taiwan are placed in the third tier. In Ogasawara's interpretation, we can see inconsistencies between Japanese and European racial geography. Within East Asia, the Japanese simply claimed racial superiority over other Asians. However, superiority was left undefined as between Japan and the West. ${ }^{41}$ Such inconsistencies in Ogasawara's modification of Huntington's framework lead us to

\footnotetext{
${ }^{38}$ Ellsworth Huntington (1876-1947) taught geography at Yale (1907-1915) and after 1917 was a research associate there, devoting his time chiefly to climatic and anthropogeographic studies. In addition to Civilization and Climate (1915, rev. ed. 1924), his works include The Climatic Factor (1914) and, with S.S. Visher, Climatic Changes (1922), Principles of Human Geography (with S.W. Cushing, 5th ed. 1940) and Mainsprings of Civilization (1945).

${ }^{39}$ For environmental determinism, see Arnold (1996).

${ }^{40}$ The "Equatorial Paradox" has some exceptions. For instance, in extreme cases such as Siberian and Alaskan Eskimos in Euro-America, Ainu versus Japanese, and Mongolians versus Hans, for East Asian cases, the principle may be apt to change.

${ }^{41}$ It is well documented that the Japanese felt inferior to Westerners, both physically and culturally, and that this led to some Japanese trying to better themselves by adopting a Western lifestyle, such as drinking milk and eating meat. They even favored interracial marriages to Caucasians (to make the Japanese physically bigger and stronger). For more about inferiority and superiority complexes concerning the Japanese, see Tsukahara,「「知的優位性のエコノミックス」としての「科学」，そして「記憶の ポリティックス」としての「歴史」：「科学と帝国主義」という観点から見た「近代日本の 科学」」, "Science as the economics of intellectual dominance, and history as the politics of memory: Modern Japanese science viewed from Science and Empires", 加藤尚武他編 (in Kato et al. eds.), 『科学 技術のゆくえ』Future of Techno-science, pp.100-119, 1998. 

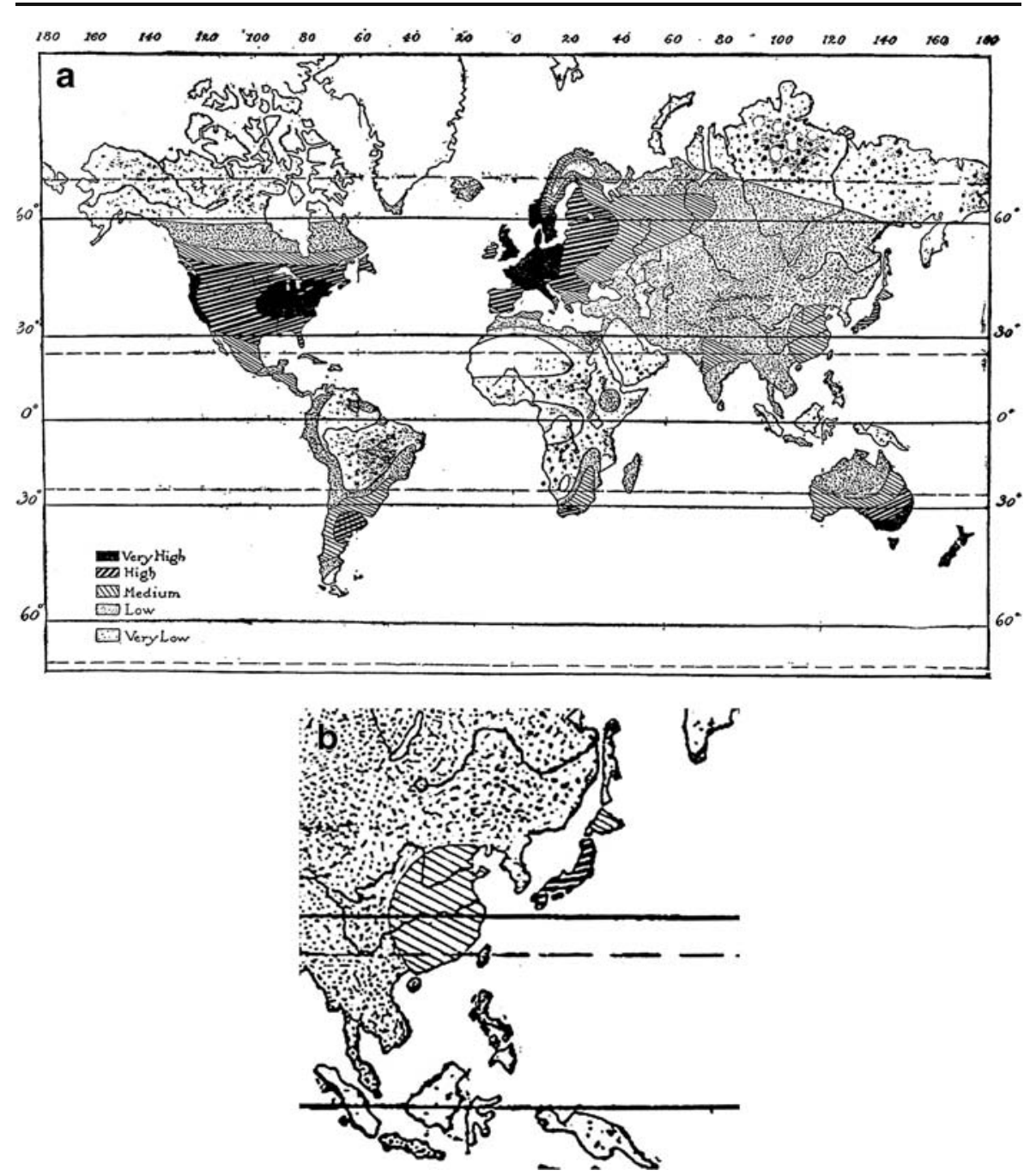

Fig. 3 a Map "Degree of Civilization" by Huntington; b Huntington's enlarged map of the East Asian region

suspect a Japanese inferiority complex toward the West, which undermines Japan's claim of superiority over the rest of Asia.

In order to complete his task, Ogasawara set out to compile the original works of Western colonial meteorologists, and to summarize the literature produced by his Imperial predecessors. To be a late starter in the colonial science race in southeastern Asia was not always a disadvantage. Because of the range of previous works, Ogasawara's compilation covered a wider area than any of them did, and reflected a strong orientation toward strategic planning and colonial management.

Japanese scientists were not only following Western models, but tried to act like independent imperial scientists. As shown by Ogasawara's proposal to expand Japan's imperial territories into Australia and New Zealand, his climatological expansionism is double-edged. His Huntingtonian interpretation might oppose Euro- 

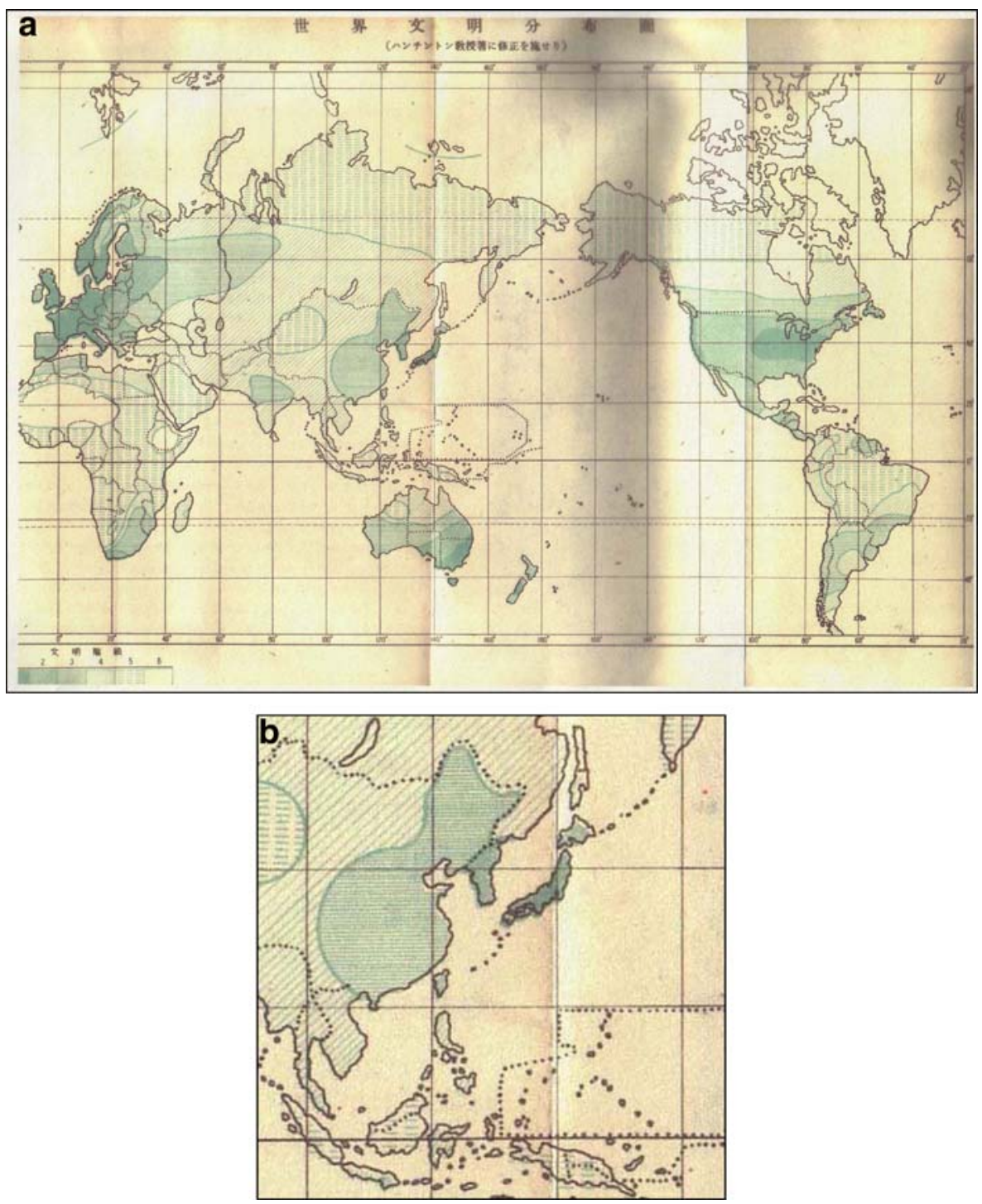

Fig. 4 a Map "Degree of Civilization" by Ogasawara; b Ogasawara's enlarged map of the East Asian region

American centrism but, at the same time, it originates from views of Japanese supremacy over other Asians. In this combination, we can point out that he was pragmatic, not on principle, but in practice.

\section{Concluding Remarks}

From the life and work of Ogasawara, we can extrapolate a typical pattern among Japanese colonial scientists. Beginning his career as a pure scientist, he gradually 曾 Springer 
worked more in applied science. Along the way, through his visit to the Philippines and exchanges with a Euro-American colonial scientist, he questioned his identity and chose to pursue science as a nationalist, rather than to devote himself to the universal values of science.

Some may believe that Japanese colonial scientists were second-rate scientists, and that their work contains little of the originality that normal science demands. Ogasawara's work shows that he tended to focus on adjustment and acclimatization, and the possibility of Japanese agricultural management. However, his accumulation was practical and useful, because he combined all the results from the Western colonial sciences into one consistent and coherent work. Like later Japanese technological successes by Toyota and Sony, the technical advantages are often referred to as an assembly and re-configuration of Euro-American inventions. In Taiwan, we can see that the colonial context of academic institutionalization supported Ogasawara's works and the networking of meteorological observatories. We have shown how Ogasawara maneuvered within meteorology as a disciplinary framework, from pure science to applied science. In the institutional and academic setting of meteorology, Ogasawara carried out his colonial science with Japan's overseas network of meteorological observatories, and made full use of the scientific resources that were firmly established in the "Three Institutions System of Meteorology," which centered on the Central Meteorological Observatory in Tokyo, its Marine Observatory in Kobe, and the Aerological Observatory in Tukuba. It is no wonder that Taihoku Imperial University was an institutional base for Ogasawara's academic works.

Syncretism created its own difficulties, which Ogasawara experienced. Science is not simply technically adaptable, but is embedded in a socio-ideological context and, in practice, its problems are not easily solved. When Ogasawara faced an American scientist, he was doubly bound between the values of science and the values of his nation; when he encountered a racist interpretation of geography, he combined Eurocentrism and Japanese supremacy.

In 1945, Ogasawara was accused of being a war criminal for his collaboration with the army, but he was said to have been released thanks to a letter from Deppermann to the General Headquarters of the Occupation Army. Still, little more than a decade post-war, he was divested of a public office, and had no academic position or stable job. He was said to live on farming and occasional odd jobs, while also performing research in his home province, Yamagata. However, after being purged from public service and academic work for more than 10 years, he succeeded in returning to academia as a Professor of Geography at Toyama University, majoring in climate and water management. There he is known to have engaged in the nation's mega-scale public construction work, the fourth Kurobe Dam building project, as a scientific adviser. This dam was completed in 1963 and was a remarkable cornerstone in Japan's post-war economic rehabilitation. In this way, he contributed to Japan's economic growth in the latter half of the twentieth century. After that, ironically, Ogasawara returned to the Philippines, where he visited with a military weather forecasting mission. This time, he was Japan's ODA (Overseas Development Aid) engineer, when he was to build a water supply network in Manila, in a project that used money from Japan's war compensation. The respectable scientific master Deppermann was no longer there, but Ogasawara 
convinced the government that building a water supply for the poor, and helping with underdeveloped nations, were tasks for advanced nations such as Japan. In Ogasawara's life, a strong continuity emerged between colonial experience as a climatologist and economic development. Such continuity led him to developmental aid projects in southeast Asia, which then emerged as lucrative markets for Japan. Deppermann was no longer present in Ogasawara's Phillippines, but Ogasawara was again under the American umbrella, and was eager to apply his knowledge for the people in the southern territories. He was not a scientist at the side of soldiers of Japan's Empire, but he was still a scientific soldier for development.

Acknowledgements The authors were supported in this research by the Ministry of Education, Culture, Sports, Science and Technology, Grant-in-Aid for Scientific Research A (Grant No. 17200049, 20052008) and for JSPS Fellows (Grant No. 17-3855). This paper is based on oral presentations at a workshop for History of Science in the Taihoku Imperial University, held in Taipei in April 2006, Taiwan, and at the 7th International East Asian STS Conference in Kobe in January 2007, Japan.

\section{References}

Arnold, D. (1996). The problem of nature: Environment, culture and European expansion. Oxford: Blackwell.

Bassala, G. (1967). The spread of western science. Science, 156, 611-622.

Clancey, G. (2006). Earthquake nation: The cultural politics of japanese seismicity, 1868-1930. Berkeley: University of California Press.

Galison, P. (1999). Trading zone: Coordinating action and belief. In M. Biagioli (Ed.), The science studies readers (pp. 137-160). New York: Routledge.

Iwao, S. (1941). Nanyo Nihon-machi no Kenkyu (南洋日本町の研究), 南亞文化研究所 (p. 367). Tokyo: Chijin-shokan.

Kato, S. (1998).「植民地における科学技術の歴史叙述について (On historiography of science and technology in colonies)」, 『科学史 科学哲学』. History and Phylosophy of Science, Departmental Journal of HPS, Tokyo University, 14, 38-46.

Kato, S. (2001).「科学の外延 : 植民地科学史の視点から (Extension of Sciences: viewed from history of colonial science)」, 『現代思想』. Japanese Journal of Revue de la Pansee d'Aujour d'Hui, 29$10,176-185$.

Kondo, K. (1899). Climate in Taiwan. Kisyo-Syushi [Journal of the Meteorological Society of Japan], $18.4,213-234$.

Kondo, K. (1917). Earthquake in Puli, Nantou. Kisyo-Syushi [Journal of the Meteorological Society of Japan], 36.3, 96-102.

Kondo, K., \& Teramoto, S. (1918). Earthquake in Swatow on the 13th February 1918. Kisyo-Syushi [Journal of the Meteorological Society of Japan], 37.5, 153-166.

Krishna, V. V. (1979). The emergence of national science in India. Indian Journal of History of Science, $15,105-113$.

Kumar, D. (1992). Patterns of colonial science in India. In P. Petitjean \& C. Jami (Eds.), Science and empires. Dordrecht: Kluwer.

Lewis, J. M. (2003). Ooishi's observation: Viewed in the context of Jet Stream discovery. Bulletin of the American Meteorological Society, 84, 357-369.

MacLeod, R. (1987). On visiting the 'moving metropolis': Reflections on the architecture of Imperial science. In N. Reingold \& M. Rothenberg (Eds.), Scientific colonialism: A cross-cultural comparison (pp. 215-249). Washington, DC: Smithsonian Institution Press.

Miyagawa, T. (2006). On the works by Wada Yuji in the Academia of Meterology in Japan 『和田雄治の 日本気象学界における業績について』. Graduation Thesis, Kobe University, March.

Murakami, Y. (1994). Kagakusha toha Nanika『科学者とは何か』. Tokyo: Shincho Press.

Nakayama, S. (1965). The role played by Universities in scientific and technological development in Japan. Cahiers d'Histoire Mondiale, 9, 340-362. 
Nakayama, S. (1970). Survey of science in colonialism. Japanese Studies in the History of Science, 10, $17-21$.

Ogasawara, K. (1945). Nampo-Kikou-Ron (南方氣候論: Climatology of the Tropics). Tokyo: Sanseido (三省堂).

Palladino, P., \& Worboys, M. (1993). Science and imperialism. ISIS, 84, 91-102.

Pyenson, L. (1989). Pure learning and political economy: Science and European expansion in the age of imperialism. In New trends in the history of science (pp. 209-278). Amsterdam: Atlanta.

Rogaski, R. (2004). Hygienic modernity: Meanings of health and disease in the treaty-port China Berkeley: University of California Press.

Sangwan, S. (1991). Science, technology and colonialism: An indian experience, 1757-1857 (pp. 29-43). New Delhi: Anamika Prakashan.

Tsukahara, T. (2002). Westernization from different angles: Review of historiography of science from the viewpoint of colonial science. In G. Clancey et al. (Eds.), Historical perspectives on east asian science, technology and medicine (pp. 279-284). Singapore: U.P.

Tsukahara, T. (2006a). Rangaku, Global Warming, Science and Empires: History and Climate, based on Dutch Historical Archive (「蘭学・地球温暖化・科学と帝国主義：歴史と気候、オランダ史 料」). Bulletin of Historiographical Institute of Tokyo University (『東京大学史料編纂所研究紀 要』), 16, 79-108 (March). esp. pp. 100-102.

Tsukahara, T. (2006b). Science and empires: History of science in Japan's Colonial Imperial Universities (『科学と帝国主義：日本植民地の帝国大学の科学史』). Kobe and Tokyo: Koseisha (皓星社).

Wada, Y. (1895). Construction project of meteorological observatories in Taiwan. Kisyo-Syushi [Journal of the Meteorological Society of Japan], 14.5, 236-254.

Wu, M. (2005).「植民地大学とその戦後」 (Colonial University in the postwar period, 吳他編 (ed. by Wu et al.). In 『記憶する台湾：帝国との相克』(Taiwan Memories: Conflicts with the Empire) (pp. 293-339). Tokyo.

Zaiki, M., Können, G.P., Tsukahara, T., Jones, P.D., Mikami, T., \& Matsumoto, K. (2006). Recovery of 19th century Tokyo/Osaka meteorological data in Japan. International Journal of Climatology, 26, 399-423.

Ziman, J. (1994). Prometeus bound. Cambridge: Cambridge University Press. 